\title{
Bibliography of hydrobiological research on the Gemenc and Béda - Karapancsa floodplains of the River Danube (1498 - 1436 rkm) including the publications of the Danube Research Institute of the Hungarian Academy of Sciences between 1968 and 2017
}

\author{
Á. BERCZIK \& M. DINKA \\ Árpád Berczik \& Mária Dinka, Hungarian Academy of Sciences, Centre for Ecological Research, \\ Danube Research Institute 1113. Budapest, Karolina út 29.E-mails: berczik.arpad@okologia.mta.hu; \\ dinka.maria@outlook.hu
}

\begin{abstract}
A compilation of the published research from the Danube Drava National Park on the Gemenc and BédaKarapancsa floodplains of the River Danube is presented. 79 publications are included which were focused on this area and accomplished by the Danube Research Institute.
\end{abstract}

Keywords. Bibliography, floodplains, Danube-Drava National Park, Gemenc, Béda-Karapancsa.

\section{INTRODUCTION}

$\mathrm{T}$ he Danube River is $c a .2850 \mathrm{~km}$ long. Its middle section, which crosses the Carpathian Basin is accompanied by a $c a .25000$ hectare active floodplain (having a water level fluctuation of $8 \mathrm{~m}$ ) with several side arms. This area represents a unique natural resource in Europe and from 1996 it was designated as the Danube Drava National Park, a Ramsar site, and included as a UNESCO Biosphere Reserve.

After some pilot studies, the Danube Research Institute of the Hungarian Academy of Sciences together with the International Association for Danube Research (IAD) in 1996 organized its $31^{\text {st }}$ conference in Baja near the Gemenc floodplain. The purpose of this conference was to highlight the extraordinary value of this area and the need for more comprehensive research programmes in the region. It also emphasised the growing significance of research on active floodplains. Following the conference the Hungarian Academy of Sciences and different Hungarian state research funds (like AKP, OTKA, KAC, NKFP) agreed to fund further research in the area. It was of special significance that, thanks to the invitation of professor Dr. Emil Dister (Aueninstitut Rastatt, Germany), our institute could submit a common tender in collaboration with the Aueninstitut Ratsatt to the Deutsche Bundesstiftung Umwelt (DBU, Osnabrück, Germany) for an ecological research project. This project would lay the foundation for the natural protection of the Gemenc-Béda-Karapancsa floodplains. The tender was successful and accomplished between 2006 and 2010.

The present bibliography includes all the works concerning this area. Author names of staff members of Danube Research Institute, Centre for Ecological Research of HAS are in capitals. Publications supported by the DBU financed project, the names of authors are written in bold.

\section{LIST OF PUBLICATIONS}

\section{8}

1. TÓTH, J. (1968): A mellékágak jelentősége (The importance of side arms). Halászat, 14: 173-174. (in Hungarian) 
1978-79

2. BOTHÁR, A. (1978-1979): Untersuchung der Crustacea-fauna im toten Arm „Alte Donau” bei Bátmonostor (Südungarn). Annales Universitatis Scientiarum Budapestinensis de Rolando Eötvös Nominatae, Sectio biologica, 20-21: 237-247.

3. RÁTH, B. (1978-79a): Untersuchung der Laichkrautvegetation eines toten Armes in der Umgebung von Baja. Annales Universitatis Scientiarum Budapestinensis de Rolando Eötvös Nominatae, Sectio biologica, 20-21: 137-153.

4. RÁTH, B. (1978-79b): Laichkraut-Phytomassenuntersuchungen im toten Arm „Alte Donau” bei Bátmonostor (Südungarn). Annales Universitatis Scientiarum Budapestinensis de Rolando Eötvös Nominatae, Sectio biologica, 20-21: 155-162.

\section{0-81}

5. BOTHÁR, A. (1980-1981): Vergleichende Untersuchung der Crustacea-Gemeinschaften im Nebenarm „Alte Donau” und im Hauptstrom (Stromkm 1481). Annales Universitatis Scientiarum Budapestinensis de Rolando Eötvös Nominatae, Sectio biologica, 22-23: 159-174.

\section{0}

6. Frank, C., Jungbluth, J., Richnovszky, A. (1990): Die Mollusken der Donau vom Schwarzwald bis zum Schwarzen Meer (eine monographische Darstellung). MTA ÖBKI, Budapest, 142 pp.

\section{7}

7. TATÁR, D. (1997): Die Wasser- und Sumpfpflanzen des Gemencer Augebietes. IAD Wien Limnologische Berichte Donau, 1997: 245-250.

\section{8}

8. TATÁR, D. (1998): Recent water macrophytes studies on the Gemenc flood plain of the Danube (1498-1468 river $\mathrm{km})$. International Workshop and $10^{\text {th }}$ Macrophyte Group Meeting IAD/SIL, Danube-Delta, (Braila)/Romania, 24-28 August, p. $86-89$.

\section{9}

9. GUTI, G. (1999): Syrman-géb (Neogobius syrman) a Duna magyarországi szakaszán. (Vorkommen der Fischart (Neogobius syrman) an der ungarischen Donau). Halászat, 92(1): 30-33. (in Hungarian)

\section{0}

10. PUKY, M. (2000a): Distribution of Decapoda species along the Hungarian Danube Section and some Tributaries with special Emphasis on their Conservation Status. International Association for Danube Research, Limnological Reports, 33: 285-290.

11. PUKY, M. (2000b): A comprehensive three-year herpetological survey in the Gemenc Region of the Duna-Dráva National Park, Hungary. Opuscula Zoologica Budapest, 32: 113-128.

12. STETÁK, D. (2000a): Adatok a Duna-Dráva Nemzeti Park Gemenci Tájegysége flórájához. (Angaben zur Flora des Gemencer Auwaldes.). Kitaibelia, 5(1): 145-176. (in Hungarian)

13. STETÁK, D. (2000b): Aquatic Macrophytes in the "Gemenc" floodplain of the Danube-Drava National Park (South Hungary). International Association for Danube Research, Limnological Reports, 33: 137-142.

\section{1}

14. GUTI, G. (2001): Water bodies in the Gemenc floodplain of the Danube, Hungary (A theoretical basis for their typology). Opuscula Zoologica Budapest, 33: 49-60.

\section{2}

15. GUTI, G. (2002): Significance of side-tributaries and floodplains for Danubian fish populations. Archiv für Hydrobiologie Supplement: 141(1-2), Large Rivers, 13(1-2): 151-163. doi: $10.1127 / / \mathrm{r} / 13 / 2002 / 151$

16. PUKY, M., Fodor, A. (2002): Occurrence of amphibian deformities along the Hungarian section of the River Danube, Tisza and Ipoly. International Association for Danube Research, Limnological Reports, 34: 845-852.

\section{3}

17. BERCZIK, Á. (2003): Miért van szükség a gemenci vizek hidrobiológiai vizsgálatára? In. SOMOGYVÁRI, O. (Ed.) Elet a Duna-ártéren - természetvédelemről sokszemközt címü tudományos tanácskozás összefoglaló kötete, Duna-Dráva Nemzeti Park Igazgatóság \& Bajai Ifjúsági Természetvédelmi Egyesület, Pécs, p. 7-10. (in Hungarian)

18. DINKA, M. (2003): Hasonlóságok és eltérések a gemenci Duna-szakasz és mellékágak vizkémiájában. (Änlichkeiten und Verschiedenheiten der wasserchemischen Charakteristika der Donau und ihrer Nebenarmen bei Gemenc). Élet a Dunaártéren - természetvédelemröl sokszemközt címü tudományos tanácskozás összefoglaló kötete, 
Duna-Dráva Nemzeti Park Igazgatóság \& Bajai Ifjúsági Természetvédelmi Egyesület, Pécs, p. 11-24. (in Hungarian)

19. Janauer, A.G., STETÁK, D. (2003): Macrophytes of the Hungarian lower Danube valley (14981468 river-km). Archiv für Hydrobiologie Supplement: 147(1-2), Large Rivers, 14(1-2): 167180. doi: $\underline{10.1127 / \mathrm{lr} / 14 / 2003 / 167}$

20. PUKY, M. (2003): Gemenc herpetológiai jelentösége és a Délkelet-Dunántúl kétéltü - hüllö ponttérképezésének eredményei. (Herpetologische Bedeutung des Gemencer Auwaldes). Élet a Duna-ártéren - természetvédelemről sokszemközt címü tudományos tanácskozás összefoglaló kötete, Duna-Dráva Nemzeti Park Igazgatóság \& Bajai Ifjúsági Természetvédelmi Egyesület, Pécs, p. 113-122. (in Hungarian)

21. SCHÖLL, K. (2003): Planktonikus Rotatoria együttesek alakulása a Duna-Dráva Nemzeti Park Gemenci Területén. (Plaktonische Rotatorien in den Gewässer von Gemenc). Élet a Duna-ártéren - természetvédelemröl sokszemközt címü tudományos tanácskozás összefoglaló kötete, DunaDráva Nemzeti Park Igazgatóság \& Bajai Ifjúsági Természetvédelmi Egyesület, Pécs, p. 30-35. (in Hungarian)

22. SZABÓ, E. (2003): The use of the tetrazolium reduction test for the detection of the terminal electron transport system (ETS) activity in decomposing reed (Phragmites australis /Cav./ Trin. ex Steud.) rhizome. Annales de Limnologie - International Journal of Limnology, 39(1): 6370. doi: $10.1051 / \mathrm{limn} / 2003006$

23. STETÁK, D. (2003): A Duna-Dráva Nemzeti Park Gemenci Tájegysége vízi növénytársulásairól. Botanikai Közlemények, 90(1-2): 35-63.

\section{4}

24. BERCZIK, Á., Buzetzky, Gy. (2004): A rehabilitáció realitásai a Duna gemenci árterén. (Die Realität einer Rehabilitation am Gemencer Donauauwald). Hidrológiai Közlöny, 84: 96-102 (in Hungarian)

25. PUKY, M. (2004): Zoological mapping along the Hungarian lower Danube: importance, aims and necessity discussed with the example of three unrelated groups, Decapoda, Amphibia and Reptilia. Internat. International Association for Danube Research, Limnological Reports, 35: 613618.
26. SCHÖLL, K. (2004a): A planktonikus kerekesféreg-állományok változásai gemenci ártér (Duna) eltérő jellegü mellékágaiban. [Changes in the planktonic Ritifer assemblages in different riverarms of the floodplain Gemenc (Danube).] (Schwankungen in der Zusammensetzung der Rotatoriengemeinschaften in den verschiedenartigen Nebenarmen des Gemencer Auwaldes). Hidrológiai Közlöny, 84: 130-132. (in Hungarian)

27. SCHÖLL, K. (2004b): Planktonic rotifer communities in the side arms of the Danube River at Gemenc (Danube-Dráva National Park, Hungary). International Association for Danube Research, Limnological Reports, 35: 555-562. (in Hungarian)

\section{5}

28. Csabai, Z., NOSEK, J. (2005): Aquatic Beetle Fauna of Gemenc Landscape Protection Area, South Hungary (Coleoptera: Hydradephaga, Hydrophiloidea). Acta biologica Debrecina, Supplementum oecologica Hungarica, 14: 67-76.

29. Csabai, Z., NOSEK, J., OERTEL, N. (2005): Aquatic Beetle Fauna of Béda-Karapancsa Landscape Protection Area, South Hungary (Coleoptera: Hydradephaga, Hydrophiloidea). Acta biologica Debrecina, Supplementum oecologica Hungarica, 13: 29-35.

30. DINKA, M., BERCZIK, Á. (2005): Néhány vizkémiai paraméter különbözösége a gemenci mellékágakban. (Wasserchemische Verschiedenheiten in Gemencer Nebenarmen). In. TAMÁs, E.A. (Ed.) Élet a Duna-ártéren - ember a természetben. Bajai Ifjúsági Természetvédelmi Egyesület, Baja, p. 58-67. (in Hungarian)

31. GUTI, G. (2005): A Duna és a hullámtéri vizterek közötti oldalirányú kölcsönhatások jelentösége a halállomány biológiai sokféleségének megörzésében. (Die Bedeutng der lateralen Interaktionen zwischen der Donau und ihren Augewässern für die Erhaltung der biologischen Vielfalt des Fischbestandes). In. TAMÁs, E.A. (Ed.) Élet a Duna-ártéren - ember a természetben. Bajai Ifjúsági Természetvédelmi Egyesület, Baja, p. 51-57. (in Hungarian)

32. KISS, K.T. (2005): Gemenc térségi vizek fitoplanktonjának elemzése természetvédelmi nézőpontból. (Phytoplankton analysis of different water bodies in the Gemenc area from a nature 
conservation point of view). Botanikai Közlemények, 92(1-2): 85-118. (in Hungarian)

33. SCHÖLL, K. (2005): Eltérö jellegü gemenci viztér-típusok Rotatoria együttesei. (Rotatoriengemeinschaften in Gemencer Wasserräume mit verschiedenem Charakter). In. TAMÁs, E.A. (Ed.) Élet a Duna-ártéren - ember a természetben. Bajai Ifjúsági Természetvédelmi Egyesület, Baja, p. 68-74. (in Hungarian)

34. SCHÖLL, K., DINKA, M. (2005): Hidrológiai folyamatok, vízkémiai paraméterek és a planktonikus Rotatoria együttesek kapcsolatai a RezétiHolt-Dunában (Duna-Dráva Nemzeti Park Gemenci Területe). (Zusammenhänge zwischen Hydrologie, Wasserchemie und planktonische Rotatorienfauna im einem Nebenarm des Gemencer Auwaldes). Hidrológiai Közlöny, 85(6): 122123. (in Hungarian)

35. STETÁK, D. (2005): A Duna-Dráva Nemzeti Park Gemenci Tájegysége mocsári és mocsárréti növénytársulásairól. (Studies on the marsh and meadow plant communities of the Gemenc area of the Danube-Drava National Park). Botanikai Közlemények, 92(1-2): 119-157. (in Hungarian)

\section{6}

36. BERCZIK, Á., Buzetzky, Gy. (2006): Realistic restoration of the Gemenc region of the Danubian floodplain based on hydroecological priorities. Verhandlungen des Internationalen Verein Limnologie, 29: 1595-1599.

37. DINKA, M., SCHÖLL, K., KISS, A. (2006): Water level and chemical characteristics related to zooplankton in a side arm of the River Danube. Verhandlungen des Internationalen Verein Limnologie, 29: 1417-1422.

38. KISS, A. (2006): Cladocera, Ostracoda and Copepoda assemblages in different side-arms of the Danube in Gemenc floodplain (DanubeDráva National Park, Hungary). Proceedings, $36^{\text {th }}$ International Conference of IAD. (Limnological Reports 36.) Austrian Committee Danube Research/IAD Vienna, p. 250-254.

39. NOSEK, J., OERTEL, N. (2006): A magyar Duna szakaszjellege a makroszkopikus gerinctelen társulások alapján. (Section types in the Hungarian reach of river Danube according to the macroinvertebrate communities). Acta biologica Debrecina, Supplementum oecologica Hungarica, 14: 175-184. (in Hungarian)
40. SCHÖLL, K. (2006): Changes in rotifer communities regarding to the water-level fluctuations in the floodplain Gemenc, Danube (Hungary). Opuscula Zoologica Budapest, 35: 77-81.

41. SCHÖLL, K., DINKA, M., BERCZIK, Á., KISS, A., ÁGOSTON-SZABÓ, E., Schmidt, A., Fehér, G. (2006): Hydrobiological differences in the Danubian water system with periodically connections with the Danube (Gemenc floodplain, Danube-Drava National Park, Hungary). Proceedings $36^{\text {th }}$ International Conference of IAD. (Limnological Reports 36.) Austrian Committee Danube Research/IAD Vienna, p. 338-342.

\section{7}

42. KISS, A. (2007): Kisrák (Cladocera, Ostracoda, Copepoda) együttesek. Microcrustacean (Cladocera, Ostracoda, Copepoda) assemblages. In. NoseK J., Oertel N. (Ed.) „A Dunának, mely múlt, jelen s jövendő..." 50 éves az MTA Magyar Dunakutató Állomása (1957-2007). MTA ÖBKIMDÁ Göd-Vácrátót, p. 51-55. (in Hungarian)

43. NOSEK, J. (2007): Contribution to the macroinvertebrate fauna of the Hungarian Danube. I. Introduction, sampling sites and methods. Folia historico-naturalia Musei Matraensis, 31: 15-41.

44. SCHÖLL, K. (2007a): Planktonikus Rotatoria együttesek jellegzetes hidrológiai helyzetekben a Duna Gemenci Árterén. (Planktonic Rotifera assemblages in typical hydrological situation at the Gemenc floodplain of the Danube ). $\mathrm{PhD}$ Thesis, ELTE TTK, Biológia Doktori Iskola, Budapest, 142 pp. (in Hungarian)

45. SCHÖLL, K. (2007b): Kerekesféreg (Rotatoria) együttesek összetételének dinamikus változásai. (Dynamic changes in the composition of rotifer (Rotifera) assemblages). In. NOSEK J., OERTEL N. (Ed.) „A Dunának, mely múlt, jelen s jövendő...” 50 éves az MTA Magyar Dunakutató Állomása (1957-2007). MTA ÖBKI-MDÁ Göd-Vácrátót, p. 57-63. (in Hungarian)

\section{8}

46. SCHÖLL, K. (2008): Planktonikus kerekesféregegyüttesek diverzitásviszonyai a Gemenci Ártér viztereiben. (Diversity of planktonic Rotifer assemblages in the floodplain Gemenc (DunaDráva National Park, Hungary). In. TAMÁs, E.A. (Ed.) Élet a Duna-ártéren - határtalan természet. Bajai Ifjúsági Természetvédelmi Egyesület, Baja, p. 97-112. (in Hungarian) 
47. SCHÖLL, K., DINKA, M. (2008): Rotatoria együttesek változó hidrológiai feltételek mellett (Gemenci Tanulmányok). (Rotifer assemblages under different hydrological conditions (DunaDráva National Park, Hungary). Hidrológiai Közlöny, 88(6): 178-180. (in Hungarian)

48. SCHÖLL, K., DINKA, M., KISS, A. (2008): Water regime indicated hydrobiological differences between two side arms in the Gemenc floodplain (Danube/Hungary). Proceedings of the 37th IAD Conference, 29.10-1.11.2008, Chisinau Moldova, p. 168-173.

49. SCHÖLL, K., DINKA, M., KISS, A., ÁGOSTON-SZABÓ, E. (2008): Hydrobiological surveys in specific hydrological situations at the Gemenc floodplain of the Danube (Hungary). In. Gumiero, B., Rinaldi, M., FoKkens, B. (Eds.) Proceedings of the ECRR Conference, Venice, Italy, p. 139-148.

50. SCHÖLL, K., KISS, A. (2008): Spatial and temporal distribution patterns of zooplankton assemblages (Rotifera, Cladocera, Copepoda) in the water bodies of the Gemenc Floodplain (Duna-Dráva National Park, Hungary). Opuscula Zoologica Budapest, 39: 65-76.

51. NOSEK, J., OERTEL, N. (2008): Similarity patterns of macroinvertebrate communities in the Hungarian Danube and adjacent wetlands (Szigetköz and Gemenc). Large Rivers, 18(1-2): 243256. doi: $10.1127 / 1 \mathrm{r} / 18 / 2008 / 243$

\section{9}

51. KISS, A., SCHÖLL, K. (2009a): Adatok a Duna Gemenci árterének Rotatoria és Crustacea (Cladocera, Ostracoda, Copepoda) faunájához (Rotatoria and Microcrustacea (Cladocera, Ostracoda, Copepoda) fauna of the Gemenc Floodplain). Hidrológiai Közlöny, 89(6): 133-135. (in Hungarian)

52. KISS, A., SCHÖLL, K. (2009b): Checklist of the Crustacea (Cladocera, Ostracoda, Copepoda) fauna in the active floodplain area of the Danube (1843-1806 rkm, $1669 \mathrm{rkm}$ and 1437-1489 rkm). Opuscula Zoologica Budapest, 40(2): 27-39.

53. SCHÖLL, K. (2009a): Diversity of planktonic rotifer assemblages in the water bodies of the Gemenc floodplain (Duna-Dráva National Park, Hungary). Biologia, 64(5): 951-958. doi: $\underline{10.2478 / \mathrm{s} 11756-009-0153-0}$
54. SCHÖLL, K. (2009b): Planktonikus kerekeféreg-együttesek diverzitásmintázata a gemenci hullámtéren (Diversity of planktonic Rotifer assemblages in the floodplain Gemenc /Duna-Dráva National Park, Hungary/). Hidrológiai Közlöny, 89(6): 169-171. (in Hungarian)

55. SCHÖLL, K. (2009c): Spatial and temporal diversity patterns of planktonic rotifer assemblages in water bodies of the Floodplain Gemenc (Duna-Dráva National Park, Hungary). International Review of Hydrobiology, 95(6): 450-460. doi: 10.1002/iroh.201011281

56. SCHÖLL, K., DINKA, M., KISS, A., ÁGOSTON-SZABÓ, E., BERCZIK, Á. (2009): $A$ Duna vizjárásának hidrobiológiai hatásai a Duna gemenci hullámterének mellékágaiban. (The hydrobiological impacts of the water regime of the Danube in the side arm of the Gemenc active floodplain). In. TÖRÖK K., KISS K.T., KERTÉSZ, M. (Eds.) Válogatás az MTA Ökológiai és Botanikai Kutatóintézet kutatási eredményeiből. ÖBKI Mühelyfüzetek, 2: 105-113. (in Hungarian)

57. SCHÖLL, K., KISS, A. (2009): Checklist of the planktonic rotifer fauna in the active floodplain area of the Danube (1843-1806 rkm, $1669 \mathrm{rkm}$ and 1437-1489 rkm). Opuscula Zoologica Budapest, 40(2): 63-73.

58. SCHÖLL, K., KISS, A., DINKA, M., ÁGOSTON-SZABÓ, E., Schmidt, A., Fehér, G., BERCZIK, Á. (2009): A gemenci hullámtér víztereinek hidrobiológiai különbségei (DunaDráva Nemzeti Park). (The hydrobiological differences of the water bodies in the Gemenc active floodplain (Danube-Dráva National Park). MHT XXVII. Országos Vándorgyülés, 2009. július 1-3 Baja, 6. szekció, p. 1-11. (in Hungarian)

2010

59. ÁGOSTON-SZABÓ, E., DINKA, M., SCHÖLL, K., KISS, A., BERCZIK, Á. (2010): Leaching losses with special references on nutrient dynamics from five leaf litter species in a side arm of the Danube at Gemenc floodplain, Hungary. Proceedings, 38th IAD Conference, June 2010, Dresden, booklet 1, p. 1-6.

60. DINKA, M., SCHÖLL, K., ÁGOSTON-SZABÓ, E., KISS, A., BERCZIK, Á. (2010): Water chemical characteristics and the spatio-temporal patterns of zooplankton assemblages in a side arm of the Danube (1437-1440 rkm, Hungary). 
Proceedings, 38 th IAD Conference, June 2010, Dresden, booklet 2, 1-6.

61. KISS, A., SCHÖLL, K., DINKA, M., ÁGOSTON-SZABÓ, E., BERCZIK, Á. (2010): Spatial differences of the zooplankton assemblages and chemical characteristics of water in a plesiopotamal side-arm of the Gemenc Floodplain Area (Duna-Dráva National Park, Hungary). Proceedings, 38 th IAD Conference, June 2010, Dresden, booklet 3, p. 1-6.

62. SCHÖLL, K. (2010): Spatial and temporal diversity patterns of planktonic rotifer assemblages in water bodies of the Floodplain Gemenc (Duna-Dráva National Park, Hungary). International Review of Hydrobiology, 95(6): 450-460. doi: 10.1002/iroh.201011281

63. SCHÖLL, K., KISS, A., DINKA, M., ÁGOSTON-SZABÓ, E., BERCZIK, Á. (2010): Spatio-temporal patterns of zooplankton densities according to water chemical caracteristics and hydrological events in a river-floodplain system (Duna-Dráva National Park, Hungary). Proceedings, 38 th IAD Conference, June 2010, Dresden, booklet 4, p. 1-6.

64. ÁGOSTON-SZABÓ, E., DINKA, M., SCHÖLL, K., KISS, A., BERCZIK, Á. (2010). A vizkémiai jellemzök és a zooplankton együttesek tér-és idöbeli eltérései a Külsö-Béda holtágban (Spatial and temporal differences of the chemical characteristics of water and the zooplankton assemblages in the Külsö-Béda dead-arm). In. TAMÁs E.A. (Ed.) Élet a Duna ártéren. Bajai Ifjúsági Természetvédelmi Egyesület, Baja, p. 11-18. (in Hungarian)

2012

65. ÁGOSTON-SZABÓ E., DINKA, M., SCHÖLL, K., KISS, A., BERCZIK, Á. (2012): Linking sediment mineralization processes with nutrient dynamics of a Danube oxbow (Gemenc, Hungary). International Association for Danube Research, Limnological Reports, 39: 133-141.

66. SCHÖLL, K., KISS, A., DINKA, M., BERCZIK, Á. (2012): Flood-pulse effects on zooplankton assemblages in a river-floodplain system (Gemenc floodplain of the Danube, Hungary). International Review of Hydrobiology, 97: 41-54. doi: 10.1002/iroh.201111427
2013

67. ÁGOSTON-SZABÓ, E., SCHÖLL, K., DINKA, M. (2013a): Limnological characteristics of a Danube oxbow-lake (Danube-Dráva National Park, Hungary). River Systems, 20(3-4): 277287. doi: $\underline{10.1127 / 1868-5749 / 2013 / 0055}$

68. ÁGOSTON-SZABÓ, E., DINKA, M., SCHÖLL, K. (2013b): The influence of hydrological connectivity on nutrient dynamics of a Danube oxbow (Danube-Dráva National Park, Hungary). In. SISÁK, I. (Ed.) COST Action 869 Proceedings of International Conference on Realistic Expectations for Improving European Waters, Budapest, p. 139-146.

69. Devetter, M., SCHÖLL, K. (2013) Hydrobiont animals in floodplain soil: Are they positively or negatively affected by flooding? Soil Biology \& Biochemistry, 69: 393-397. doi: $\underline{10.1016 / \text { j.soilbio.2013.11.005 }}$

2014

70. ÁGOSTON-SZABÓ, E., SCHÖLL, K., KISS, A., BERCZIK, Á., DINKA, M. (2014): Decomposition of Willow Leaf Litter in an Oxbow Lake of the Danube River at Gemenc, Hungary. Acta Zoologica Bulgarica, Suppl. 7: 197-202.

71. Kalchev, R., DINKA, M., Beshkova, M., Kalcheva, H., BERCZIK, Á., ÁGOSTON-SZABÓ, E. (2014): Factors influencing chemical characteristics and the nutrient retention/release potential of wetlands in the Middle (Hungarian) and Lower (Bulgarian) Danube River. Acta Zoologica Bulgarica, Suppl. 7: 75-82.

72. Kazakov, S., SCHÖLL, K., Kalchev, R., Pehlivanov, L., KISS, A. (2014): Comparison of zooplankton species diversity in Hungarian and Bulgarian Danube sections. Acta Zoologica Bulgarica, Suppl. 7: 91-96.

73. KISS, A., ÁGOSTON-SZABÓ, E., DINKA, M., SCHÖLL, K., BERCZIK, Á. (2014): Microcrustacean (Cladocera, Copepoda, Ostracoda) Diversity in Three Side Arms in the Gemenc Floodplain (Danube River, Hungary) in Different Hydrological Situations. Acta Zoologica Bulgarica, Suppl. 7: 135-141.

74. TARJÁNYI, N., BERCZIK, Á. (2014): Spatial distribution of phytophilous macroinvertebrates in a side arm of Middle Danube River. Acta Zoologica Bulgarica, Suppl. 7: 13-19. 


\section{5}

75. KISS, A., ÁGOSTON-SZABÓ, E., DINKA, M., BERCZIK, Á. (2015): Microcrustacean diversity in the Gemenc-Béda-Karapancsa Floodplains (Danube-Drava National Park, Hungary): rare and alien species. Opuscula Zoologica Budapest, 46: 183-197.

doi: $10.18348 /$ opzool.2015.2.183

\section{6}

76. ÁGOSTON-SZABÓ, E., SCHÖLL, K., KISS, A., DINKA, M. (2016). Mesh size and site effects on leaf litter decomposition in a side arm of the River Danube on the Gemenc floodplain (Danube-Dráva National Park, Hungary). Hydrobiologia, 774(1): 53-68. doi: $10.1007 / \mathrm{s} 10750-015-2616-3$

77. Kalchev, R., BERCZIK, Á., Beshkova, M., DINKA, M., Kalcheva, H., KISS, A., ÁGOSTON-SZABÓ E. (2016): Trophic status and phytoplankton limitation conditions in a few
Bulgarian and Hungarian Danube River wetlands. Transylvanian Review of Systematical \& Ecological Research, 18(2): 19-28. doi: 10.1515/trser2015-0084

78. Kalcheva, H., DINKA, M., ÁGOSTON-SZABÓ, E., BERCZIK, Á., Kalchev, R., TARJÁNYI, N., KISS, A. (2016): Bacterioplankton from two Hungarian Danube River Wetlands (Béda-Karapancsa, Danube-Drava National Park) and its relations to environmental variables. Transylv. Transylvanian Review of Systematical \& Ecological Research, 18(1): 1-12. doi: $\underline{10.1515 / \text { trser-2015-0075 }}$

2017

79. ÁGOSTON-SZABÓ, E., SCHÖLL, K., KISS, A., DINKA, M. (2017): The Effects of Tree Species Richness and Composition on Leaf Litter Decomposition in a Danube Oxbow Lake (Gemenc, Hungary). Fundamental and Applied Limnology, 189(4): 301-314 